\title{
Short UV-C Treatment Prevents Browning and Extends the Shelf-Life of Fresh-Cut Carambola
}

\author{
Carlota Moreno, ${ }^{1}$ María J. Andrade-Cuvi, ${ }^{1}$ María J. Zaro, ${ }^{2,3}$ Magali Darre, ${ }^{2,3}$ \\ Ariel R. Vicente, ${ }^{2,4}$ and Analía Concellón ${ }^{2}$ \\ ${ }^{1}$ Facultad de Ciencias de la Ingeniería, Universidad Tecnológica Equinoccial, Av. Occidental y Mariana de Jesús (Campus Occidental), \\ EC170129 Quito, Ecuador \\ ${ }^{2}$ CIDCA (Centro de Investigación y Desarrollo en Criotecnología de Alimentos) (CCT La Plata CONICET-UNLP), Calle 47 y 116, \\ 1900 La Plata, Argentina \\ ${ }^{3}$ Facultad de Ciencias Agrarias y Forestales, Universidad Nacional de La Plata (UNLP), Calle 60 y 119, 1900 La Plata, Argentina \\ ${ }^{4}$ LIPA (Laboratorio de Investigación en Productos Agroindustriales), Facultad de Ciencias Agrarias y Forestales, \\ Universidad Nacional de La Plata (UNLP), Calle 60 y 119, 1900 La Plata, Argentina
}

Correspondence should be addressed to María J. Zaro; mariajosezarol6@hotmail.com

Received 26 July 2016; Revised 22 November 2016; Accepted 12 December 2016; Published 15 January 2017

Academic Editor: Vicente M. Gómez-López

Copyright @ 2017 Carlota Moreno et al. This is an open access article distributed under the Creative Commons Attribution License, which permits unrestricted use, distribution, and reproduction in any medium, provided the original work is properly cited.

In this work, we selected a short UV-C treatment for fresh-cut carambola and assessed its efficacy in supplementing the benefits of low temperature storage. UV-C treated $\left(6.0,10.0\right.$, and $\left.12.5 \mathrm{~kJ} \mathrm{~m}^{-2}\right)$ carambola slices showed reduced deterioration compared to control fruit. Treatment with a dose of $12.5 \mathrm{~kJ} \mathrm{~m}^{-2} \mathrm{UV}-\mathrm{C}$ was more effective in maintaining quality and was selected for subsequent experiments evaluating the combination of UV-C and refrigeration on fruit storability and physical, chemical, and microbiological properties. Short UV-C exposure reduced weight loss and electrolyte leakage. UV-C treated carambola slices presented higher phenolic antioxidants than control after $21 \mathrm{~d}$ at $4^{\circ} \mathrm{C}$ and showed no alterations in soluble solids or titratable acidity. UV-C exposure also reduced the counts of molds, yeast, and aerobic mesophilic bacteria. UV-C treated fruit showed a fresh-like appearance even after $21 \mathrm{~d}$ as opposed to control carambola which presented spoilage and extensive browning symptoms. The reduction of fruit browning in UV-C treated fruit was not due to reduction in phenylalanine-ammonia lyase (PAL) and/or peroxidase (POD), but rather through polyphenol oxidase (PPO) inhibition and improved maintenance of tissue integrity.

\section{Introduction}

The fresh-cut industry has been increasing greatly due to high demand for healthy and ready to use products [1]. Fresh-cut fruits are perceived as a good option because of their high quality and reduced wastage and preparation time. However, minimal processing markedly reduces products shelf-life by accelerating deteriorative reactions such as overripening, tissue discoloration, and spoilage [1]. Enzymatic browning caused by the oxidation of phenolic compounds by polyphenol oxidases (PPO) or peroxidases (POD) is a major cause of deterioration in fresh-cut fruits [2]. Several studies have tested the efficacy of food additives to prevent browning by inhibiting phenolics oxidation and/or by maintaining tissue integrity, with variable success $[3,4]$. However, some of these chemicals such as sulfites which are highly effective to prevent browning are banned in many countries for fresh vegetables intended to be used in a raw state [5]. The use of synthetic additives is also restricted in the growing segment of fresh-cut organic produce [6]. On the other hand, thermal treatments are routinely used by the food industry prior to further processing steps (drying, freezing) to control browning and other deterioration reactions. However, their application in fresh-cut fruits is limited since the conditions required to fully denature deterioration enzymes would be detrimental in physiologically active commodities [1]. Besides, hot air treatments need relatively long exposure time and are difficult to couple to processing lines, whereas dipping heat treatments 
may increase water and energy use. Consequently, there is great interest in the search for nonthermal/nonchemical treatments that may contribute to the control of browning and maintenance of the fresh-like appearance of products, intended to be consumed in the raw state [2].

Short UV-C treatment is a nonthermal and clean strategy that may be relatively simply coupled to processing lines $[1,7]$. Given its direct antimicrobial effect, UV-C radiation may be used for surface sanitation [8]. UV-C was effective to delay softening in tomato [9] and peach [10] and to delay senescence in broccoli [11] and mango [12]. Moreover, UV$\mathrm{C}$ treatments have been shown to exert some physiological effects on fresh-cut fruit $[7,13]$. The effects of UV-C on phenolic metabolism have been well documented [2, 14]. However, the observed responses depend on both the fruit system and treatment conditions [15]. UV-C irradiation has upregulated phenylalanine-ammonia lyase (PAL) and induced the accumulation of phenolic compounds in some $[13,16,17]$ but not in all cases [18]. The catabolism of phenolic compounds was also modulated by mild UV-C treatments in a different manner depending on the system considered; they prevented their oxidation in fresh-cut apples $[19,20]$ as opposed to lettuce and grapefruit where browning was favored $[14,21]$.

Carambola (Averrhoa carambola L.), also known as "starfruit," has large aptitudes as fresh-cut product due to its star-like shape slices, resulting attractive garnish for desserts and salads [22]. It is produced in Asian countries and tropical areas of America, with great potential for export markets. Carambola does not show significant softening during postharvest storage and in this respect it is satisfactory for minimal processing; however, the fruit is highly susceptible to browning and spoilage [22]. To our knowledge no studies have been conducted to assess the efficacy of UV-C radiation to extend the postharvest life of carambola fruit. The aim of the present work was to select a suitable UV-C dose and to evaluate the effects of this treatment on browning and microbiological quality as a strategy to prolong the shelf-life of fresh-cut carambola.

\section{Materials and Methods}

2.1. Plant Material. Carambola fruit cv. Dulce produced in Babahoyo (Los Ríos, Ecuador) was harvested at commercial maturity based on surface color and immediately transported to the laboratory. Fruit was selected for uniformity (size and color) and absence of defects, washed with chlorinated water (100 $\mathrm{mg} \mathrm{L}^{-1} \mathrm{NaClO}, 3 \mathrm{~min}, \mathrm{pH} 7.0$ ), and cut transversally to the main axis into $5 \mathrm{~mm}$ slices.

\subsection{UV-C Treatment}

2.2.1. UV-C Dose Selection. An initial experiment was conducted to select the most suitable UV-C dosage. Trays containing the carambola slices were located under a bank of 4 UV-C lamps (Philips, TUV G30T8, $30 \mathrm{~W}$, USA; emission peak $254 \mathrm{~nm}$ ) at $30 \mathrm{~cm}$ and subjected to irradiation doses of $6.0,10.0$, or $12.5 \mathrm{~kJ} \mathrm{~m}^{-2}$ measured with a digital radiometer (UVP, UVX Radiometer, USA). Slices were manually rotated to reach the desired UV-C dose on each side. Carambola slices processed as indicated above but without UV-C treatment were used as control. Control and UV-C treated trays were covered with perforated PVC film and stored at $4^{\circ} \mathrm{C}$ for 21 days. Six trays containing ca. $100 \mathrm{~g}$ of carambola slices (20-24 slices) were visually evaluated for each treatment as indicated in Section 2.3.1. The whole experiment was repeated three times.

2.2.2. Combination of UV-C Treatment and Refrigerated Storage. Carambola fruit was harvested and processed as previously indicated. Trays containing the carambola slices were located under a bank of 4 UV-C lamps and subjected to irradiation dose of $12.5 \mathrm{~kJ} \mathrm{~m}^{-2}$ as previously mentioned. Control carambola slices were not treated with UV-C lamps. Control and UV-C treated trays were covered with perforated PVC film and stored at $4^{\circ} \mathrm{C}$ for $0,7,14$, or 21 days. Six trays containing ca. $100 \mathrm{~g}$ of carambola slices (20-24 slices) were visually evaluated as described in Section 2.3. Fresh fruit was used for microbiological counts, electrolyte leakage, color, SSC, pH, acidity, and weight loss evaluations. Samples were subsequently frozen in liquid $\mathrm{N}_{2}$ and stored at $-80^{\circ} \mathrm{C}$ until phenolic and enzyme (PAL, PPO, and POD) analyses. The whole experiment was repeated three times.

\subsection{Quality Assessment}

2.3.1. Deterioration Index. Fruit deterioration was assessed by visual inspection using a four-point hedonic scale (1 = excellent, 2 = good quality, 3 = poor quality, and 4 = unacceptable quality) and deterioration index (DI) was calculated. A fruit sample with $3<$ DI $<4$ was considered not consumable. The main symptoms assessed were dehydration, firmness loss, browning development, and microbial decay. Six trays of fruit for each treatment and storage time were evaluated. The deterioration index was calculated as

$$
\begin{aligned}
& \text { DI } \\
& =\sum \frac{(\text { Damage level } \times \text { number of fruit slices per level })}{\text { Total number of fruit slices evaluated }} .
\end{aligned}
$$

2.3.2. Weight Loss. Each tray was weighted at initial time and during storage. Weight loss (WL) relative to the initial value was calculated and expressed in percentage.

2.3.3. Electrolyte Leakage. Measurements were performed as reported by Concellón et al. [23] with minor modifications. Two grams of tissue discs ( $5 \mathrm{~mm}$ thick, $10 \mathrm{~mm}$ diameter) obtained from at least six slices from different fruit trays was weighed and incubated in plastic tubes with $25 \mathrm{~mL}$ $0.6 \mathrm{~mol} \mathrm{~L}^{-1}$ mannitol at $20^{\circ} \mathrm{C}$. The conductivity of the incubating solution was measured with a conductometer (Model 510, Oakton, Vernon Hills, IL, USA) at the beginning of the experiment and after $3 \mathrm{~h}$ of incubation. The fruit discs were subsequently homogenized and centrifuged at $6,000 \times \mathrm{g}$ for $15 \mathrm{~min}$ and conductivity of the supernatant was measured as indicated before. Results were expressed as a percentage 
of total electrolytes leaked out of the tissues after $3 \mathrm{~h}$. Three replicates were prepared for each treatment and storage time.

2.3.4. Soluble Solids Content (SSC). Samples of at least six slices from different trays were ground in a food grinder (Philips, Mixer HR1363 Turbo, Brazil) and filtered through a cloth. SSC was determined with a refractometer (Boeco, B\&C Hand Refractometer 30103, Germany). Three measurements were performed for each treatment and storage time. Results are expressed in \% w/w.

2.3.5. $p H$ and Acidity. Samples of at least six slices from different trays were ground in a food grinder and $15 \mathrm{~g}$ of the resulting slurry was weighed in a beaker. One hundred milliliters of water was added and the $\mathrm{pH}$ of the solution was measured with a pH meter (Oakton, PC 510, USA). Acidity was determined by titrating with $0.1 \mathrm{~mol} \mathrm{~L}^{-1} \mathrm{NaOH}$ until $\mathrm{pH}$ 8.2. Four replicates were evaluated for each treatment and storage time. Results were expressed as g of citric acid per $100 \mathrm{~g}$ of fresh weight.

2.3.6. Color. Fruit pulp color was measured using a colorimeter (Minolta, Model CR-400, Osaka, Japan). Forty carambola slices were measured for each treatment and storage time. Sample lightness $\left(L^{*}\right)$ and hue angle were used as indicators of cut surface browning [22].

2.4. Microbiological Counts. Samples of at least six slices from different trays ( $c a .10 \mathrm{~g}$ ) were put into sterile plastic bags, diluted with $90 \mathrm{~mL}$ of sterile water, and homogenized in a stomacher. One $\mathrm{mL}$ samples from different dilutions $\left(10^{-2}\right.$ to $10^{-5}$ ) were poured into the appropriate culture medium for aerobic bacteria and yeasts and molds (Petrifilm ${ }^{\mathrm{TM}}$ plates 6400 and $6407,3 \mathrm{M}$, St. Paul, MN, USA). The plates were incubated $72 \mathrm{~h}$ at $25^{\circ} \mathrm{C}$ for yeasts and molds and $48 \mathrm{~h}$ at $37^{\circ} \mathrm{C}$ for aerobic mesophilic bacteria. Results were expressed as log of colony forming units (CFUs) per $g$ of fresh fruit. Three replicates were evaluated for each treatment and storage time.

2.5. Phenolic Compounds. Samples of at least six slices from different trays were ground in a mill (Ultracomb Mo. 8100, Ecuador) and $5 \mathrm{~g}$ of the resulting powder was weighted and homogenized with $15 \mathrm{~mL}$ ethanol. The obtained suspension was stirred for $1 \mathrm{~h}$ at $4^{\circ} \mathrm{C}$ and centrifuged at $6,000 \times \mathrm{g}$ for $10 \mathrm{~min}$ in a refrigerated centrifuge (Hermle, Z323R, Germany). The supernatant was saved and used to analyze phenolic compounds. Phenolics were evaluated with the Folin-Ciocalteu reagent [24]. Aliquots $(0.125 \mathrm{~mL})$ of ethanolic extracts prepared as described above were transferred to a tube containing $1,675 \mathrm{~mL}$ of distilled water. After that $0.2 \mathrm{~mL}$ of $1: 1$ Folin-Ciocalteu reagent was added and allowed to react for $3 \mathrm{~min}$ at $20^{\circ} \mathrm{C}$. Then $0.4 \mathrm{~mL}$ of $20 \%(\mathrm{w} / \mathrm{v}) \mathrm{Na}_{2} \mathrm{Co}_{3}$ in $0.1 \mathrm{~mol} \mathrm{~L}^{-1}$ and $0.6 \mathrm{~mL}$ of distilled water were added to reach a final volume of $3 \mathrm{~mL}$. After $90 \mathrm{~min}$ at $20^{\circ} \mathrm{C}$ the absorbance at $760 \mathrm{~nm}$ was measured in a spectrophotometer (Thermo Scientific, Evolution 60S, USA). Catechin was used as a standard and results were expressed in $\mathrm{mg}$ per $\mathrm{kg}$ of fresh weight. Measurements were done in triplicate.

\subsection{Enzyme Assays}

2.6.1. Polyphenol Oxidase (PPO) and Peroxidase (POD). Samples of at least six frozen slices from different trays were ground in a mill and $5 \mathrm{~g}$ of the resultant powder was homogenized with $15 \mathrm{~mL}$ of phosphate buffer $\left(0.1 \mathrm{~mol} \mathrm{~L}^{-1}, \mathrm{pH}\right.$; $10 \mathrm{~g} \mathrm{~L}^{-1}$ polyvinylpolypyrrolidone (PVPP) and $10 \mu \mathrm{L}$ of $0.1 \%$ $\mathrm{v} / \mathrm{v}$ Triton-X100) for $15 \mathrm{~min}$ at $4^{\circ} \mathrm{C}$. The suspension was centrifuged at $6,000 \times \mathrm{g}$ for $15 \mathrm{~min}$ at $4^{\circ} \mathrm{C}$ and the supernatant was used to assay PPO and POD activity. The reaction mixture for PPO determination contained phosphate buffer $\left(0.1 \mathrm{~mol} \mathrm{~L}^{-1}\right.$, pH 6), $0.3 \mathrm{~mL}$ of extract, and $0.2 \mathrm{~mL}$ of $0.1 \mathrm{~mol} \mathrm{~L}^{-1}$ catechol in a total volume of $3 \mathrm{~mL}$. The reaction mixture was incubated $2 \mathrm{~h}$ at $35^{\circ} \mathrm{C}$ and the enzymatic activity was determined spectrophotometrically at $410 \mathrm{~nm}$. The reaction mixture for POD determination contained phosphate buffer $\left(0.1 \mathrm{~mol} \mathrm{~L}^{-1}\right.$, $\mathrm{pH} 6), 0.3 \mathrm{~mL}$ of extract, $0.5 \mathrm{~mL}$ of $0.25 \% \mathrm{v} / \mathrm{v}$ guaiacol, and $0.16 \mathrm{~mL}$ of $0.1 \mathrm{~mol} \mathrm{~L}^{-1} \mathrm{H}_{2} \mathrm{O}_{2}$ in a total volume of $2 \mathrm{~mL}$. Measurements were done in triplicate. The increase in absorbance at $470 \mathrm{~nm}$ was recorded during $2 \mathrm{~min}$. One unit of PPO and POD activity (U) was defined as an increase of 0.001 and 0.1 units of absorbance per min at 410 and $470 \mathrm{~nm}$, respectively. Results were expressed in PPO and POD units per $g$ of fresh weight.

2.6.2. Phenylalanine-Ammonia Lyase (PAL). Samples of at least six frozen slices were ground in a mill and $5 \mathrm{~g}$ of the resultant powder was homogenized with $15 \mathrm{~mL}$ $\mathrm{Na}_{2} \mathrm{~B}_{4} \mathrm{O}_{7} \cdot 10 \mathrm{H}_{2} \mathrm{O}$ buffer $\left(100 \mathrm{mmol} \mathrm{L}^{-1}, \mathrm{pH} 8,8\right), 0.05 \mathrm{~mol} \mathrm{~L}^{-1}$ 2-mercaptoethanol, $0.002 \mathrm{~mol} \mathrm{~L}^{-1}$ disodium ethylenediaminetetraacetate dehydrate (EDTA), and $30 \mathrm{~g} \mathrm{~L}^{-1}$ polyvinylpolypyrrolidone (PVPP) for $20 \mathrm{~min}$ at $4^{\circ} \mathrm{C}$. The suspension was centrifuged at $6,000 \times \mathrm{g}$ for $30 \mathrm{~min}$ at $4^{\circ} \mathrm{C}$ and the supernatant was used to assay PAL activity. The reaction mixture contained $1.54 \mathrm{~mL}$ of $\mathrm{Na}_{2} \mathrm{~B}_{4} \mathrm{O}_{7} \cdot 10 \mathrm{H}_{2} \mathrm{O}\left(0.1 \mathrm{~mol} \mathrm{~L}^{-1}, \mathrm{pH}\right.$ 8.8), $0.06 \mathrm{~mL}$ of enzymatic extract, and $0.4 \mathrm{~mL}$ of $0.01 \mathrm{~mol} \mathrm{~L}^{-1}$ L-phenylalanine in a total volume of $2 \mathrm{~mL}$. Samples were incubated for $24 \mathrm{~h}$ at $35^{\circ} \mathrm{C}$ and the activity was determined spectrophotometrically with the increase in absorbance at $290 \mathrm{~nm}$. Extracts and measurements were done in triplicate. One unit of PAL activity (U) was defined as an increase of 0.0001 units of absorbance per min at $290 \mathrm{~nm}$. Results were expressed in PAL units per $\mathrm{g}$ of fresh weight.

2.7. Statistical Analysis. Experiments were performed according to a factorial design with time at $4^{\circ} \mathrm{C}$ and treatment as factors. Data was analyzed by ANOVA. The main effects and the interactions were analyzed and the means were compared by the Fisher test at a significance level of $P<0.05$.

\section{Results and Discussion}

3.1. UV-C Treatment Selection. To select the most suitable treatment, carambola slices were exposed to different UV$\mathrm{C}$ doses $\left(0.0 ; 6.0 ; 10.0\right.$; or $\left.12.5 \mathrm{~kJ} \mathrm{~m}^{-2}\right)$. The main causes of fruit deterioration in control carambola were browning and decay reaching a value of DI $=3.8$ after 21 days of storage (Figure 1). Treated carambola slices showed at all doses tested 


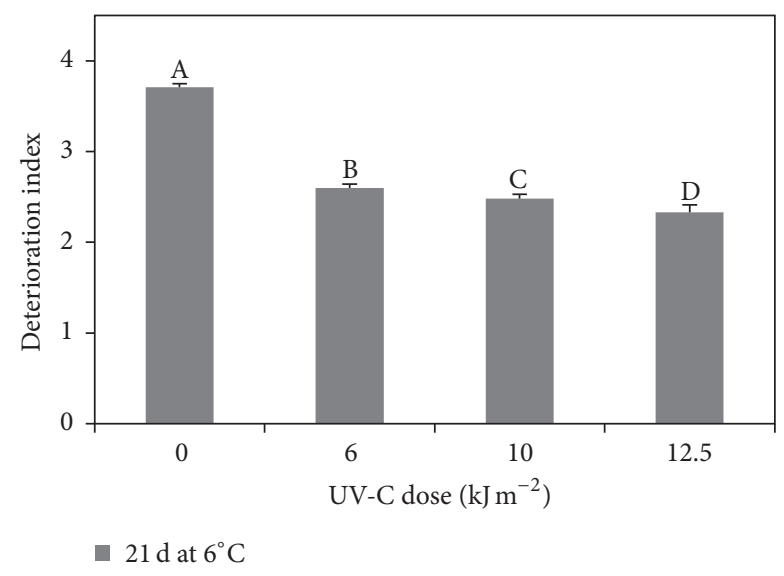

FIGURE 1: Deterioration index (DI) in carambola slices treated with 0 (control), 6,10 , or $12.5 \mathrm{~kJ} \mathrm{~m}^{-2}$ of UV-C radiation and stored for 21 days at $4^{\circ} \mathrm{C}$. Bars represent the standard error $(n=3)$. Different letters indicate significant differences on Fisher's test $(P<0.05)$.

lower DI than the control. UV-C treatment has been shown to delay ripening and reduce spoilage in other fresh-cut tropical fruits, such as mango and pineapple [8]. In this work, the effectiveness of UV treatment on quality maintenance was dependent on the applied radiation dose. The lowest DI was low in carambola slices treated with the dose $12.5 \mathrm{~kJ} \mathrm{~m}^{-2}$ which was consequently selected for further experiments analyzing the effect on fruit microbiological counts, physical and chemical properties, and enzymes involved in phenolic metabolism.

\subsection{Changes in UV-C Treated Carambola Slices during Storage}

3.2.1. Deterioration Index, Weight Loss, and Electrolyte Leakage. In a second set of experiments, control and UV-C treated $\left(12.5 \mathrm{~kJ} \mathrm{~m}^{-2}\right)$ carambola slices were stored at $4^{\circ} \mathrm{C}$ for $0,7,14$, or 21 days. Treated fruit slices showed a better visual appearance than the control throughout the storage. The differences between control and treated fruit were highly marked after 21 days (Figure 2(a)) with no appreciable browning, decay, or dehydration symptoms in irradiated fruit as opposed to the controls which were highly deteriorated. The DI increased with storage time (Figure 2(b)) in both control and treated fruit, but the differences among treatments were significant after 14 and 21 days. Control fruit reached a DI = 4.0 at the end of the storage mainly due to extensive surface of browning and tissue maceration. In contrast, UV treated slices maintained acceptable quality throughout the storage period.

Weight loss was $1.2 \%$ after 7 days with no differences between control and treated carambola (Figure 3(a)). Subsequently, UV-C treated carambola showed lower weight loss than control fruit after both 14 and 21 days. Manzocco and Nicoli [25] suggested that UV-C irradiation favored the formation of a thin dried layer in the cut surface which may increase the resistance to water flow. However, the reduction in weight loss may have resulted simply from improved maintenance of tissue integrity in UV treated fruit.
The latter is supported by the lower levels of electrolyte leakage (EL) found in UV-C treated fruit at long storage times (Figure 3(b)). After 14 and 21 days EL increased more markedly in control and was one-fold higher than that of UVC treated carambola (Figure 3(b)). This may indicate that cell disruption may overcome the hysteresis effects occurring at short storage times. Overall, results suggest that short prestorage UV-C exposure may be useful to extend carambola shelflife through preventing browning, dehydration, and tissue disruption.

3.2.2. Microbiological Counts. Immediately after treatment, a reduction of 2.5 and $1.9 \log \mathrm{CFU} \mathrm{g}^{-1}$ of aerobic mesophilic bacteria and yeasts and molds was found in UV-C treated fruit (Figures 4(a) and 4(b)). The $2 \log \mathrm{CFU} \mathrm{g}^{-1}$ reduction is comparable to that obtained with traditional hypochlorite treatments [22] and higher than that reported in many UV-C irradiation treatments in fruit surfaces $[19,20,26]$. Though bacterial and fungal counts increased in both control and treated carambola during storage, the irradiated slices still showed lower values than the control after 7 and 14 days. At the end of storage period no differences were found between control and treated fruit in bacterial counts whereas lower counts of viable fungi were still recorded. It is worth noting that the differences in decay were even more dramatic than those observed in fruit microbiological counts. This suggests that the effects of UV-C treatments on postharvest spoilage may exceed a direct germicide effect of UV-C radiation. Some studies have shown that UV treatments may favor the accumulation of antimicrobial phenolics in the fruit surfaces [13] and activate several defensive strategies [27].

\subsection{3. pH, Soluble Solids, Titratable Acidity, Color, and Brown-} ing. After treatment with UV-C light, carambola slices did not show significant variations in $\mathrm{pH}$ (ca. 3.70), soluble solids (ca. $7.10 \% \mathrm{w} \mathrm{w}^{-1}$ ), or titratable acidity (ca. $0.38 \mathrm{~g}$ $100 \mathrm{~g}^{-1}$ ) (Table 1). No major changes in $\mathrm{pH}$, SSC, and acidity were found throughout the storage period regardless of the treatment.

Immediately after irradiation UV-C treated fruit showed lower lightness and hue values than the control (Figures 5(a) and 5(b)). A similar response has been reported in other UV-C treated commodities such as white table grape [28] and broccoli $[17,29]$. In these cases, the rapid change in color induced by UV radiation was related to the degradation of chlorophylls with concomitant accumulation of brown-greenish catabolites. This was unlikely the case in carambola given the minute levels of chlorophyll remaining in the fruits at harvest. One plausible explanation is that the burst in $\mathrm{H}_{2} \mathrm{O}_{2}$ induced by UV-C radiation may provide the required cosubstrate for peroxidase-mediated phenolic oxidation [30]. Although further work is needed to address this, it is important to note that the modification of fruit color caused by UV-C radiation was subtle and seldom detected by direct observation (Figure 1(a)). A rapid reduction in fruit $L^{*}$ and hue was observed during storage, but UV-C irradiated carambola maintained higher values than the control after 7,14 , and 21 days indicating that the treatment was effective 
TABLE 1: $\mathrm{pH}$, soluble solids content, and titratable acidity in control and UV-C treated $\left(12.5 \mathrm{~kJ} \mathrm{~m}^{-2}\right)$ carambola slices stored for $0,7,14$, and $21 \mathrm{~d}$ at $4^{\circ} \mathrm{C}$. The values represent the mean \pm standard error $(n=3)$. Different letters indicate differences on Fisher's test $(P<0.05)$.

\begin{tabular}{|c|c|c|c|c|c|}
\hline & \multirow{2}{*}{ Treatment } & \multicolumn{4}{|c|}{ Time at $4^{\circ} \mathrm{C}$ (days) } \\
\hline & & 0 & 7 & 14 & 21 \\
\hline \multirow{2}{*}{$\mathrm{pH}$} & Control & $3.74 \pm 0.04^{\mathrm{a}}$ & $3.68 \pm 0.05^{\mathrm{ab}}$ & $3.67 \pm 0.05^{\mathrm{ab}}$ & $3.57 \pm 0.12^{\mathrm{b}}$ \\
\hline & UV-C & $3.68 \pm 0.09^{\mathrm{ab}}$ & $3.69 \pm 0.06^{\mathrm{ab}}$ & $3.68 \pm 0.13^{\mathrm{ab}}$ & $3.67 \pm 0.10^{\mathrm{ab}}$ \\
\hline \multirow{2}{*}{ Soluble solids (\% w/w) } & Control & $7.07 \pm 0.12^{\mathrm{ab}}$ & $7.05 \pm 0.34^{\mathrm{ab}}$ & $7.10 \pm 0.10^{\mathrm{ab}}$ & $6.80 \pm 0.16^{\mathrm{b}}$ \\
\hline & UV-C & $7.23 \pm 0.25^{\mathrm{a}}$ & $7.20 \pm 0.40^{\mathrm{a}}$ & $7.00 \pm 0.10^{\mathrm{ab}}$ & $7.13 \pm 0.06^{\mathrm{ab}}$ \\
\hline \multirow{2}{*}{ Acidity (g/100 g) } & Control & $0.38 \pm 0.01^{\mathrm{a}}$ & $0.35 \pm 0.01^{b c}$ & $0.33 \pm 0.01^{\mathrm{d}}$ & $0.33 \pm 0.02^{\mathrm{cd}}$ \\
\hline & UV-C & $0.39 \pm 0.00^{\mathrm{a}}$ & $0.36 \pm 0.01^{\mathrm{b}}$ & $0.33 \pm 0.01^{\mathrm{d}}$ & $0.32 \pm 0.02^{\mathrm{d}}$ \\
\hline
\end{tabular}
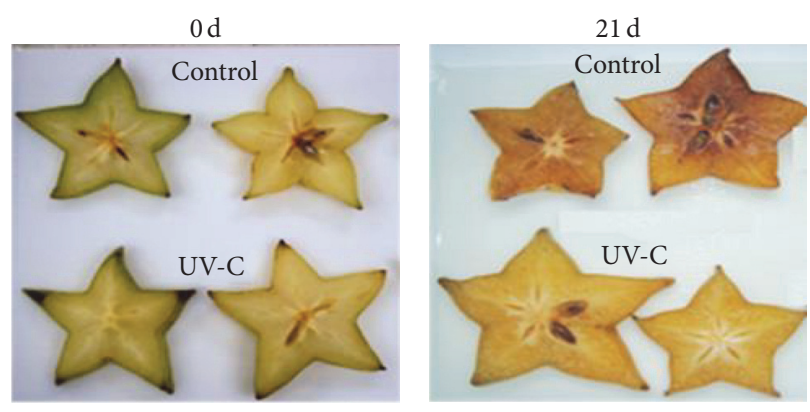

(a)

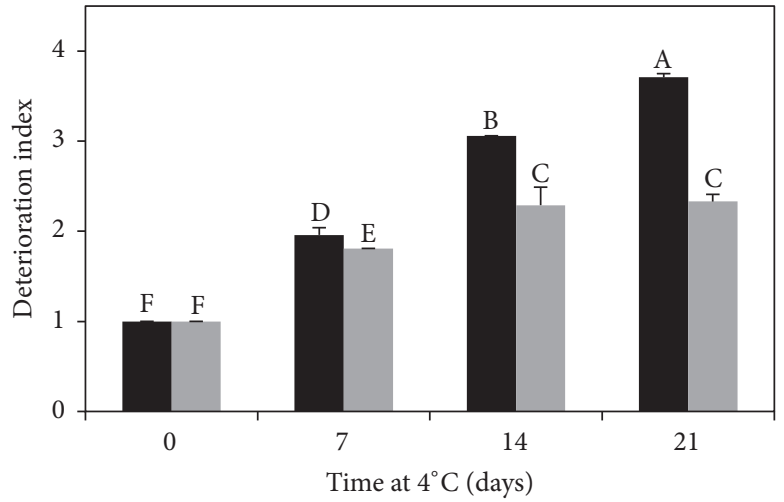

- Control

- UV-C

(b)

FIgUre 2: (a) Appearance and (b) deterioration index in control and UV-C treated $\left(12.5 \mathrm{~kJ} \mathrm{~m}^{-2}\right)$ carambola slices stored during $21 \mathrm{~d}$ at $4{ }^{\circ} \mathrm{C}$. Bars represent the standard error $(n=3)$. Different letters indicate significant differences on Fisher's test $(P<0.05)$.

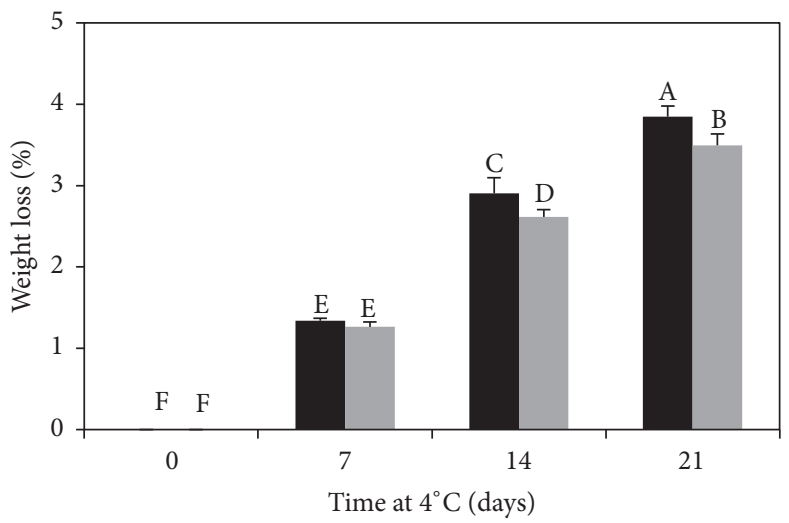

- Control

- UV-C

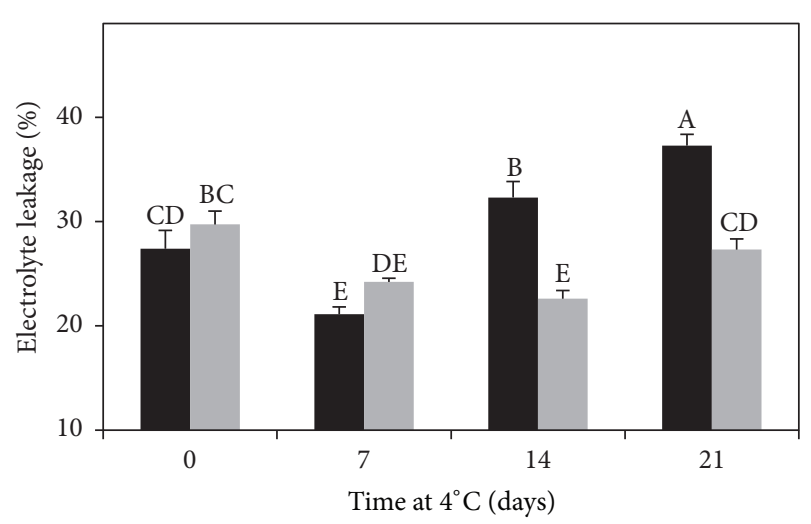

- Control

- UV-C

(a)

(b)

FIGURE 3: (a) Weight loss and (b) electrolyte leakage in control and UV-C treated $\left(12.5 \mathrm{~kJ} \mathrm{~m}^{-2}\right)$ carambola slices stored for 0, 7, 14, and $21 \mathrm{~d}$ at $4^{\circ} \mathrm{C}$. Bars represent the standard error $(n=3)$. Different letters indicate significant differences on Fisher's test $(P<0.05)$. 


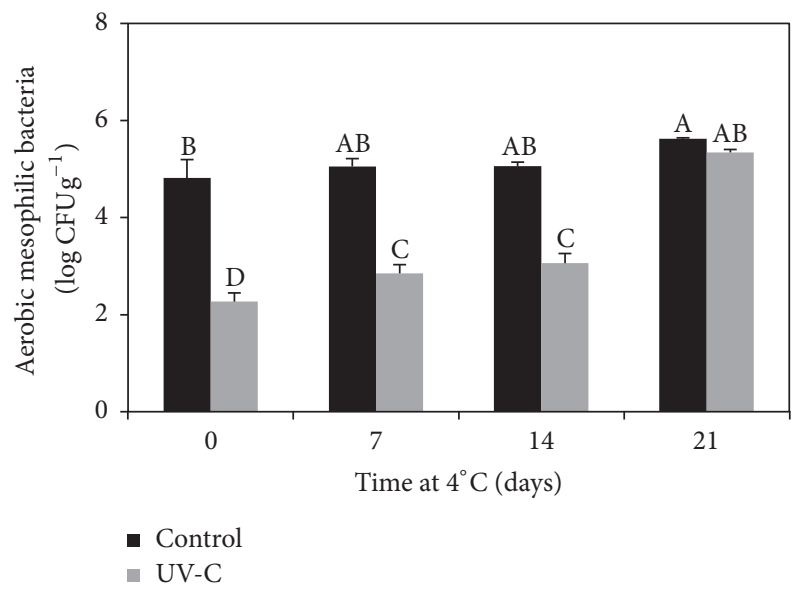

(a)

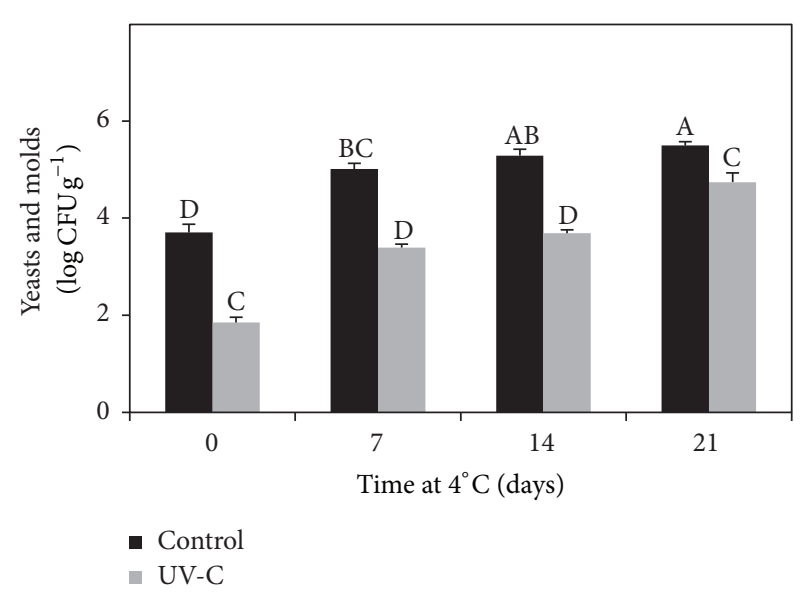

(b)

Figure 4: (a) Aerobic mesophilic bacteria and (b) yeasts and molds in control and UV-C treated $\left(12.5 \mathrm{~kJ} \mathrm{~m}^{-2}\right)$ carambola slices stored for 0 , 7,14 , and $21 \mathrm{~d}$ at $4^{\circ} \mathrm{C}$. Bars represent the standard error $(n=3)$. Different letters indicate significant differences on Fisher's test $(P<0.05)$.

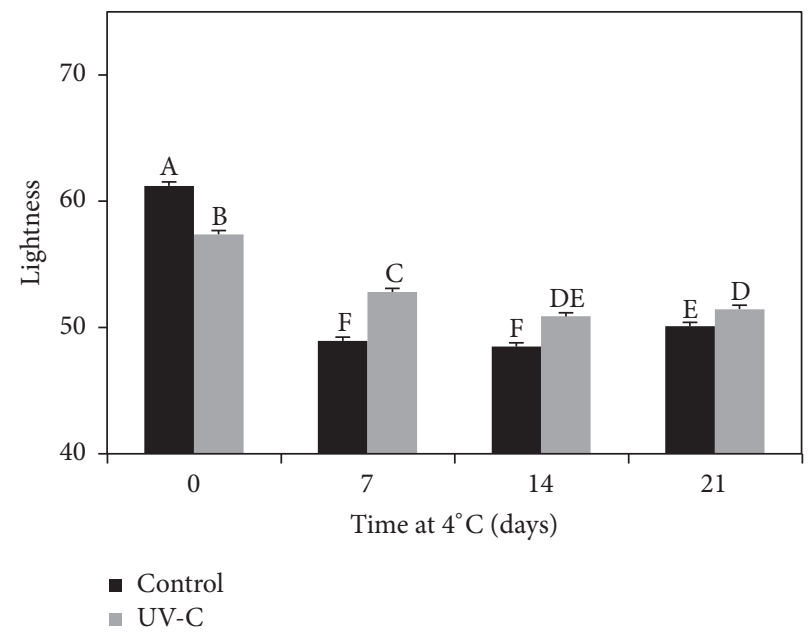

(a)

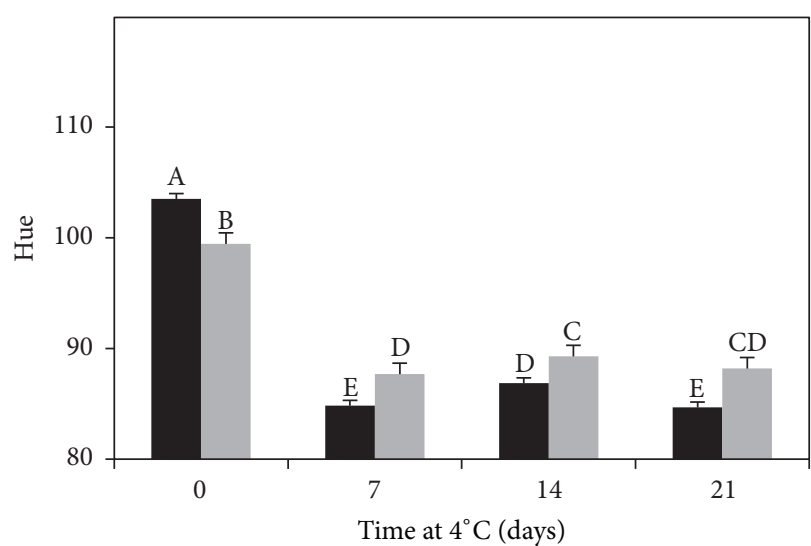

- Control

- UV-C

(b)

Figure 5: (a) Lightness and (b) hue angle in control and UV-C treated $\left(12.5 \mathrm{~kJ} \mathrm{~m}^{-2}\right)$ carambola slices stored for $0,7,14$, and $21 \mathrm{~d}$ at $4^{\circ} \mathrm{C}$. Bars represent the standard error $(n=3)$. Different letters indicate significant differences on Fisher's test $(P<0.05)$.

to prevent browning after storage without affecting other attributes that contribute to flavor such as SSC and acidity (Figures 5(a) and 5(b)).

3.2.4. Phenolic Metabolism. At harvest the level of phenolic compounds was ca. $240 \mathrm{mg} \mathrm{kg}^{-1}$ FW (Figure 6(a)). No variation in total phenolic content was found immediately after UV-C exposure. However, irradiated fruit slices showed a gradual increase specially after 14 and 21 days of storage. In contrast, the level of phenolic antioxidants showed no variations in control fruit throughout the storage period. Consequently, after 21 days UV-C treated fruit showed significantly high levels of phenolic compounds. To further understand the effect of UV radiation on phenolic metabolism we evaluated the effect of the treatment on the activities of the enzymes PAL, PPO, and POD.
In contrast to previous reports which showed that minimal processing can induce PAL in mango [12], the activity of this enzyme decreased along storage time in both control and treated carambola slices (Figure 6(b)). PAL is known to be one of the key enzymes regulating the biosynthesis of phenylpropanoid pathway in plants [31]. However, other enzymes within this pathway may in some cases be rate limiting. Some studies have also shown that the phenylpropanoid route could be regulated by complex mechanisms such as metabolic channeling [32]. These channels may regulate in vivo the net flux through the pathway by the formation of complexes between successive enzymes preventing reaction intermediated to freely diffuse. In addition, plants can synthesize phenolic compounds via the shikimate pathway and consequently the activation of this route may increase the accumulation of phenolic without appreciable differences in 


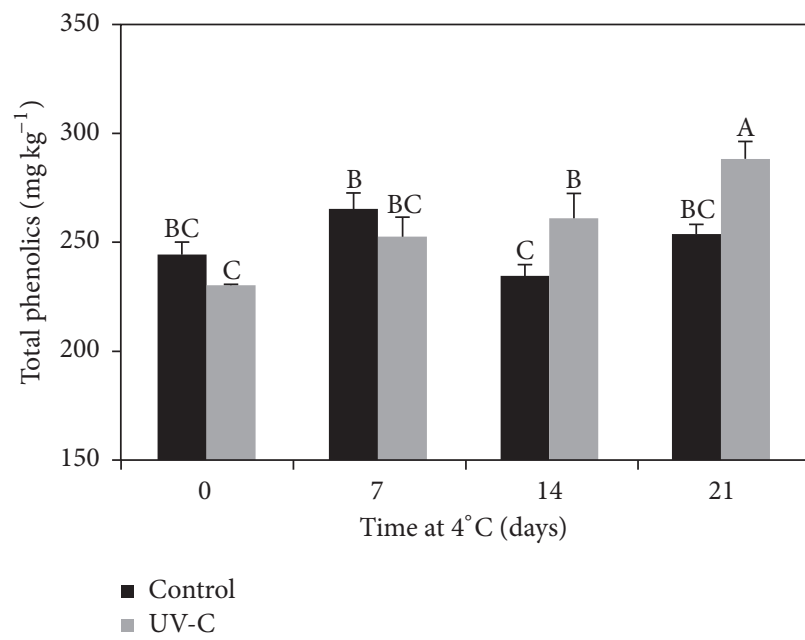

(a)

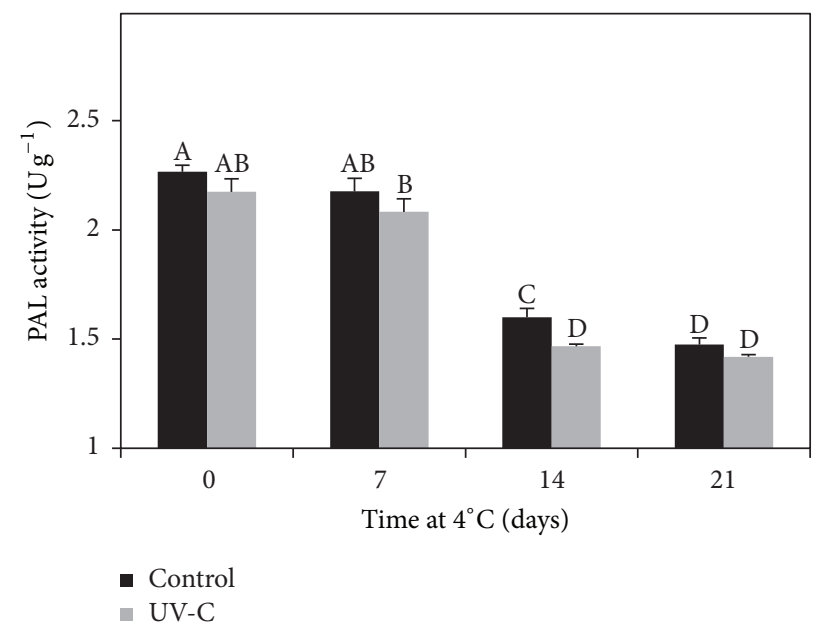

(b)

FIGURE 6: (a) Total phenolics and (b) phenylalanine-ammonia lyase (PAL) activity in control and UV-C treated $\left(12.5 \mathrm{~kJ} \mathrm{~m}^{-2}\right) \mathrm{carambola} \mathrm{slices}$ stored for $0,7,14$, and $21 \mathrm{~d}$ at $4^{\circ} \mathrm{C}$. Bars represent the standard error $(n=3)$. Different letters indicate significant differences on Fisher's test $(P<0.05)$.

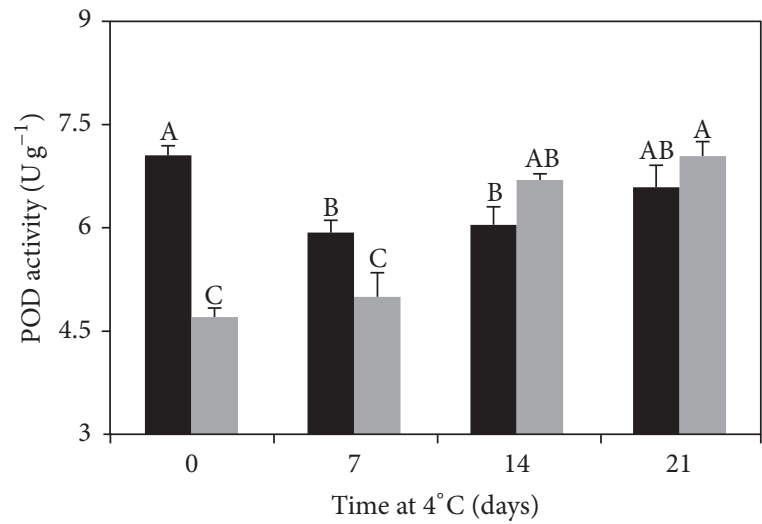

- Control

- UV-C

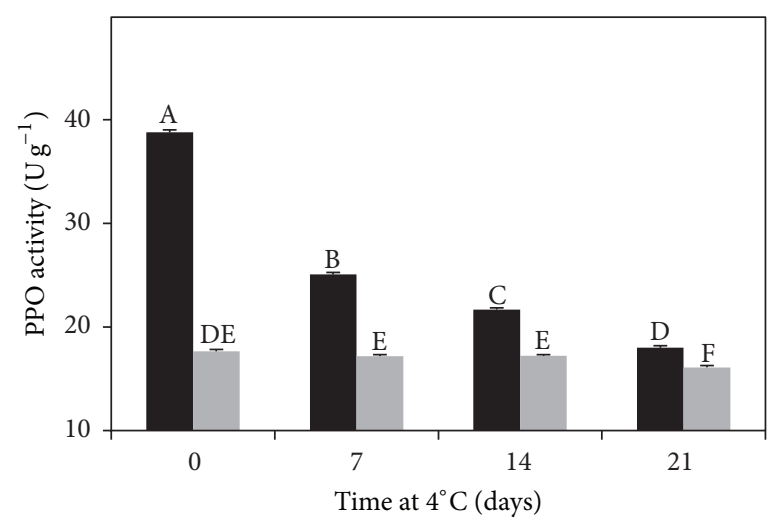

- Control

- UV-C

(a)

(b)

Figure 7: (a) Peroxidase (POD) and (b) polyphenol oxidase (PPO) activities in control and UV-C treated carambola slices stored for 0, 7, 14, and $21 \mathrm{~d}$ at $4^{\circ} \mathrm{C}$. Bars represent the standard error $(n=3)$. Different letters indicate significant differences on Fisher's test $(P<0.05)$.

PAL activity [33]. Finally, it should be acknowledged that the steady state level of phenolic within a tissue resulted from a balance between its biosynthesis and turnover. Phenolic compounds can be metabolized in a number of ways which include the oxidative polymerization to yield lignin and/or the formation of melanin-like pigments through PPO or POD [2]. The detection of PAL activity suggests that the biosynthetic route is still active. In this scenario if phenolic oxidation reactions (by PPO and/or POD) are exacerbated in control fruit this may result in a lower buildup of these compounds.

POD activity was transiently inhibited by the UV-C treatment (Figure 7(a)). Similar results have been reported in papaya [34]. POD activity increased during storage in treated fruit, showing no differences with the control at the last sampling date. Remarkably, PPO activity was dramatically inhibited by the UV-C treatment (Figure 7(b)). Manzocco et al. [35] treated a PPO enzyme solution with a wide range of UV-C intensities and found that the inhibitory effect may be related to protein aggregation rather than denaturation. Though the differences in PPO activity between control and treated carambola slices were attenuated by storage progressed, they were even significant after 21 days of storage. It is worth noting that regardless of the differences in PPO induced by the photochemical treatment the enzyme activity decreased in storage as browning manifestation occurred. This suggests that the reaction may be limited by tissue integrity rather than by the enzyme level. In this scenario, browning would be prevented in UV-C treated carambola by improved maintenance in cell compartmentalization as 
suggested by electrolyte leakage values. However, low PPO activity in UV-C treated fruit may decrease browning upon cell disruption. Overall, results show that UV-C treatment may be an effective nonchemical or nonthermal means of controlling PPO activity and browning reactions in fresh-cut carambola.

\section{Conclusions}

UV-C treatment $\left(12.5 \mathrm{~kJ} \mathrm{~m}^{-2}\right)$ reduced weight loss and yeasts and molds and bacterial counts and controlled spoilage in carambola slices. Treated fruit showed lower electrolyte leakage suggesting improved maintenance of tissue integrity. The selected treatment caused no alterations in fruit soluble solids, $\mathrm{pH}$, or titratable acidity and increased the fruit antioxidants phenolic compounds at long storage times. Prestorage UV-C exposure was highly effective to control fruit browning through PPO inhibition and improved maintenance of tissue integrity. Altogether, results show that prestorage UV-C treatment may be an appealing nonthermal technology to supplement the benefits of low temperature storage in freshcut carambola reducing spoilage, surface contamination, and browning.

\section{Additional Points}

Practical Applications. Short UV-C treatment $(12.5 \mathrm{~kJ} \mathrm{~m}-2)$ markedly reduced spoilage and PPO-mediated tissue browning and may be a simple nonchemical approach to supplement low temperature storage in fresh-cut carambola. Highlights. (i) UV-C treatments improved carambola microbiological quality. (ii) UV-C exposure $\left(12.5 \mathrm{~kJ} \mathrm{~m}^{-2}\right.$ ) reduced fruit dehydration and electrolyte leakage. (iii) UV-C treatment markedly reduced PPO activity and inhibited browning. (iv) UV-C treatment may be a nonchemical approach to complement refrigeration in fresh-cut carambola.

\section{Competing Interests}

The authors declare that there is no conflict of interests regarding the publication of this paper.

\section{Acknowledgments}

This work was supported by the Dirección de Investigación y Transferencia de Tecnología from the Universidad Tecnológica Equinoccial, Quito, Ecuador (Research Project II.UIO.ING.06) and Agencia Nacional de Promoción Científica y Tecnológica (ANPCyT) and Consejo Nacional de Investigaciones Científicas y Técnicas (CONICET), Argentina.

\section{References}

[1] D. Rico, A. B. Martín-Diana, J. M. Barat, and C. Barry-Ryan, "Extending and measuring the quality of fresh-cut fruit and vegetables: a review," Trends in Food Science and Technology, vol. 18, no. 7, pp. 373-386, 2007.

[2] F. A. Tomás-Barberán and J. C. Espín, "Phenolic compounds and related enzymes as determinants of quality in fruits and vegetables," Journal of the Science of Food and Agriculture, vol. 81, no. 9, pp. 853-876, 2001.

[3] E. Aguayo, C. Requejo-Jackman, R. Stanley, and A. Woolf, "Hot water treatment in combination with calcium ascorbate dips increases bioactive compounds and helps to maintain fresh-cut apple quality," Postharvest Biology and Technology, vol. 110, pp. 158-165, 2015.

[4] P. Ding, S. H. Ahmad, and H. M. Ghazali, "Changes in selected quality characteristics of minimally processed carambola (Averrhoa carambola L.) when treated with ascorbic acid," Journal of the Science of Food and Agriculture, vol. 87, no. 4, pp. 702-709, 2007.

[5] R. Iyengar and A. J. McEvily, "Anti-browning agents: alternatives to the use of sulfites in foods," Trends in Food Science and Technology, vol. 3, no. C, pp. 60-64, 1992.

[6] H. Ölmez and U. Kretzschmar, "Potential alternative disinfection methods for organic fresh-cut industry for minimizing water consumption and environmental impact," LWT-Food Science and Technology, vol. 42, no. 3, pp. 686-693, 2009.

[7] T. Bintsis, E. Litopoulou-Tzanetaki, and R. K. Robinson, "Existing and potential applications of ultraviolet light in the food industry-a critical review," Journal of the Science of Food and Agriculture, vol. 80, no. 6, pp. 637-645, 2000.

[8] D. S. George, Z. Razali, V. Santhirasegaram, and C. Somasundram, "Effects of ultraviolet light (UV-C) and heat treatment on the quality of fresh-cut chokanan mango and josephine pineapple," Journal of Food Science, vol. 80, no. 2, pp. S426-S434, 2015.

[9] E. Ait Barka, S. Kalantari, J. Makhlouf, and J. Arul, "Impact of UV-C irradiation on the cell wall-degrading enzymes during ripening of tomato (Lycopersicon esculentum L.) fruit," Journal of Agricultural and Food Chemistry, vol. 48, no. 3, pp. 667-671, 2000.

[10] J. Y. Lu, C. Stevens, V. A. Khan, M. Kabwe, and C. L. Wilson, "The effect of ultraviolet irradiation on shelf-life and ripening of peaches and apples," Journal of Food Quality, vol. 14, no. 4, pp. 299-305, 1991.

[11] M. L. Lemoine, P. M. Civello, G. A. Martínez, and A. R. Chaves, "Influence of postharvest UV-C treatment on refrigerated storage of minimally processed broccoli (Brassica oleracea var. Italica)," Journal of the Science of Food and Agriculture, vol. 87, no. 6, pp. 1132-1139, 2007.

[12] G. A. González-Aguilar, R. Zavaleta-Gatica, and M. E. TiznadoHernández, "Improving postharvest quality of mango 'Haden' by UV-C treatment," Postharvest Biology and Technology, vol. 45, no. 1, pp. 108-116, 2007.

[13] L. M. Rodoni, M. J. Zaro, J. H. Hasperué, A. Concellón, and A. R. Vicente, "UV-C treatments extend the shelf life of fresh-cut peppers by delaying pectin solubilization and inducing local accumulation of phenolics," LWT-Food Science and Technology, vol. 63, no. 1, pp. 408-414, 2015.

[14] G. D’Hallewin, M. Schirra, M. Pala, and S. Ben-Yehoshua, "Ultraviolet C irradiation at $0.5 \mathrm{~kJ} \cdot \mathrm{m}^{-2}$ reduces decay without causing damage or affecting postharvest quality of Star Ruby grapefruit (C. paradisi Macf.)," Journal of Agricultural and Food Chemistry, vol. 48, no. 10, pp. 4571-4575, 2000.

[15] P. M. Civello, A. R. Vicente, and G. A. Martinez, "UV-C technology to control postharvest diseases of fruits and vegetables," in Recent Advances in Alternative Postharvest Technologies to Control Fungal Diseases in Fruits \& Vegetables, Transworld Research Network, Trivandrum, India, 2007. 
[16] M. Alothman, R. Bhat, and A. A. Karim, "UV radiation-induced changes of antioxidant capacity of fresh-cut tropical fruits," Innovative Food Science and Emerging Technologies, vol. 10, no. 4, pp. 512-516, 2009.

[17] M. L. Lemoine, A. R. Chaves, and G. A. Martínez, "Influence of combined hot air and UV-C treatment on the antioxidant system of minimally processed broccoli (Brassica oleracea L. var. Italica)," LWT_Food Science and Technology, vol. 43, no. 9, pp. 1313-1319, 2010.

[18] J. Pan, A. R. Vicente, G. A. Martínez, A. R. Chaves, and P. M. Civello, "Combined use of UV-C irradication and heat treatment to improve postharvest life of strawberry fruit," Journal of the Science of Food and Agriculture, vol. 84, no. 14, pp. 1831-1838, 2004.

[19] C. Chen, W. Hu, Y. He, A. Jiang, and R. Zhang, "Effect of citric acid combined with UV-C on the quality of fresh-cut apples," Postharvest Biology and Technology, vol. 115, p. 151, 2016.

[20] L. Manzocco, S. Da Pieve, A. Bertolini et al., "Surface decontamination of fresh-cut apple by UV-C light exposure: effects on structure, colour and sensory properties," Postharvest Biology and Technology, vol. 61, no. 2-3, pp. 165-171, 2011.

[21] A. Allende, J. L. McEvoy, Y. Luo, F. Artes, and C. Y. Wang, "Effectiveness of two-sided UV-C treatments in inhibiting natural microflora and extending the shelf-life of minimally processed 'Red Oak Leaf' lettuce," Food Microbiology, vol. 23, no. 3, pp. 241-249, 2006.

[22] G. H. A. Teixeira, J. F. Durigan, R. E. Alves, and T. J. O’Hare, "Use of modified atmosphere to extend shelf life of fresh-cut carambola (Averrhoa carambola L. cv. Fwang Tung)," Postharvest Biology and Technology, vol. 44, no. 1, pp. 80-85, 2007.

[23] A. Concellón, M. C. Añón, and A. R. Chaves, "Effect of chilling on ethylene production in eggplant fruit," Food Chemistry, vol. 92, no. 1, pp. 63-69, 2005.

[24] V. L. Singleton and J. A. Rossi, "Colorimetry of total phenolics with phosphomolybdic-phosphotungstic acid reagents," American Journal of Enology and Viticulture, vol. 16, pp. 144-158, 1965.

[25] L. Manzocco and M. C. Nicoli, "Surface processing: existing and potential applications of ultraviolet light," Critical Reviews in Food Science and Nutrition, vol. 55, no. 4, pp. 469-484, 2015.

[26] F. Artés-Hernández, V. H. Escalona, P. A. Robles, G. B. Martínez-Hernández, and F. Artés, "Effect of UV-C radiation on quality of minimally processed spinach leaves," Journal of the Science of Food and Agriculture, vol. 89, no. 3, pp. 414-421, 2009.

[27] M. A. Pombo, H. G. Rosli, G. A. Martínez, and P. M. Civello, "UV-C treatment affects the expression and activity of defense genes in strawberry fruit (Fragaria $\times$ ananassa, Duch.)," Postharvest Biology and Technology, vol. 59, no. 1, pp. 94-102, 2011.

[28] R. González-Barrio, M. Salmenkallio-Marttila, F. A. TomásBarberán, E. Cantos, and J. C. Espín, "Etiology of UV-Cinduced browning in var. Superior white table grapes," Journal of Agricultural and Food Chemistry, vol. 53, no. 15, pp. 5990-5996, 2005.

[29] L. Costa, A. R. Vicente, P. M. Civello, A. R. Chaves, and G. A. Martínez, "UV-C treatment delays postharvest senescence in broccoli florets," Postharvest Biology and Technology, vol. 39, no. 2, pp. 204-210, 2006.

[30] T. M. Murphy and A. J. Huerta, "Hydrogen peroxide formation in cultured rose cells in response to UV-C radiation," Physiologia Plantarum, vol. 78, no. 2, pp. 247-253, 1990.
[31] X. Zhang and C.-J. Liu, "Multifaceted regulations of gateway enzyme phenylalanine ammonia-lyase in the biosynthesis of phenylpropanoids," Molecular Plant, vol. 8, no. 1, pp. 17-27, 2015.

[32] K. Jørgensen, A. V. Rasmussen, M. Morant et al., "Metabolon formation and metabolic channeling in the biosynthesis of plant natural products," Current Opinion in Plant Biology, vol. 8, no. 3, pp. 280-291, 2005.

[33] W. Vermerris and R. Nicholson, "Biosynthesis of phenolic compounds," in Phenolic Compound Biochemistry, pp. 63-149, Springer Netherlands, 2008.

[34] D. M. Rivera-Pastrana, A. A. Gardea, E. M. Yahia, M. A. Martínez-Téllez, and G. A. González-Aguilar, "Effect of UV$\mathrm{C}$ irradiation and low temperature storage on bioactive compounds, antioxidant enzymes and radical scavenging activity of papaya fruit," Journal of Food Science and Technology, vol. 51, no. 12, pp. 3821-3829, 2014.

[35] L. Manzocco, B. Quarta, and A. Dri, "Polyphenoloxidase inactivation by light exposure in model systems and apple derivatives," Innovative Food Science and Emerging Technologies, vol. 10, no. 4, pp. 506-511, 2009. 

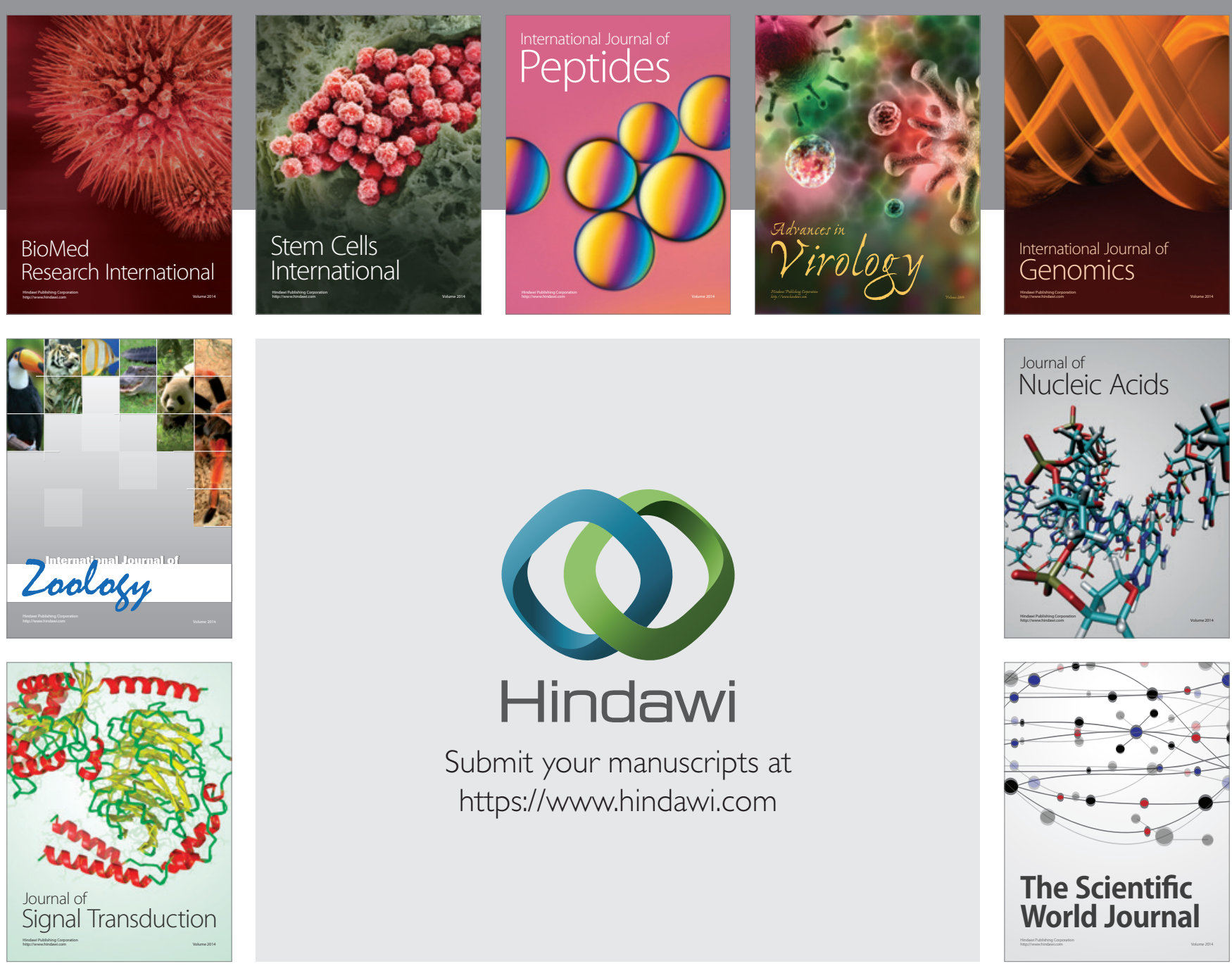

Submit your manuscripts at

https://www.hindawi.com
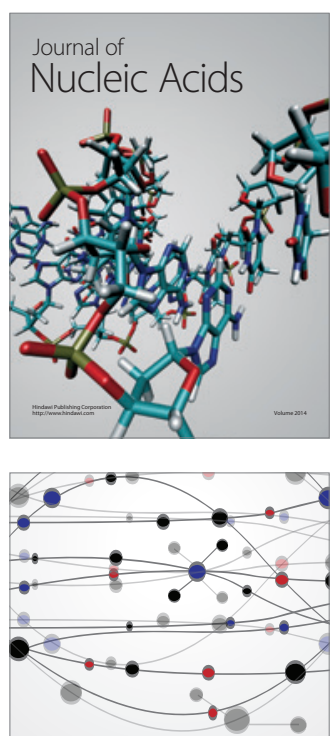

The Scientific World Journal
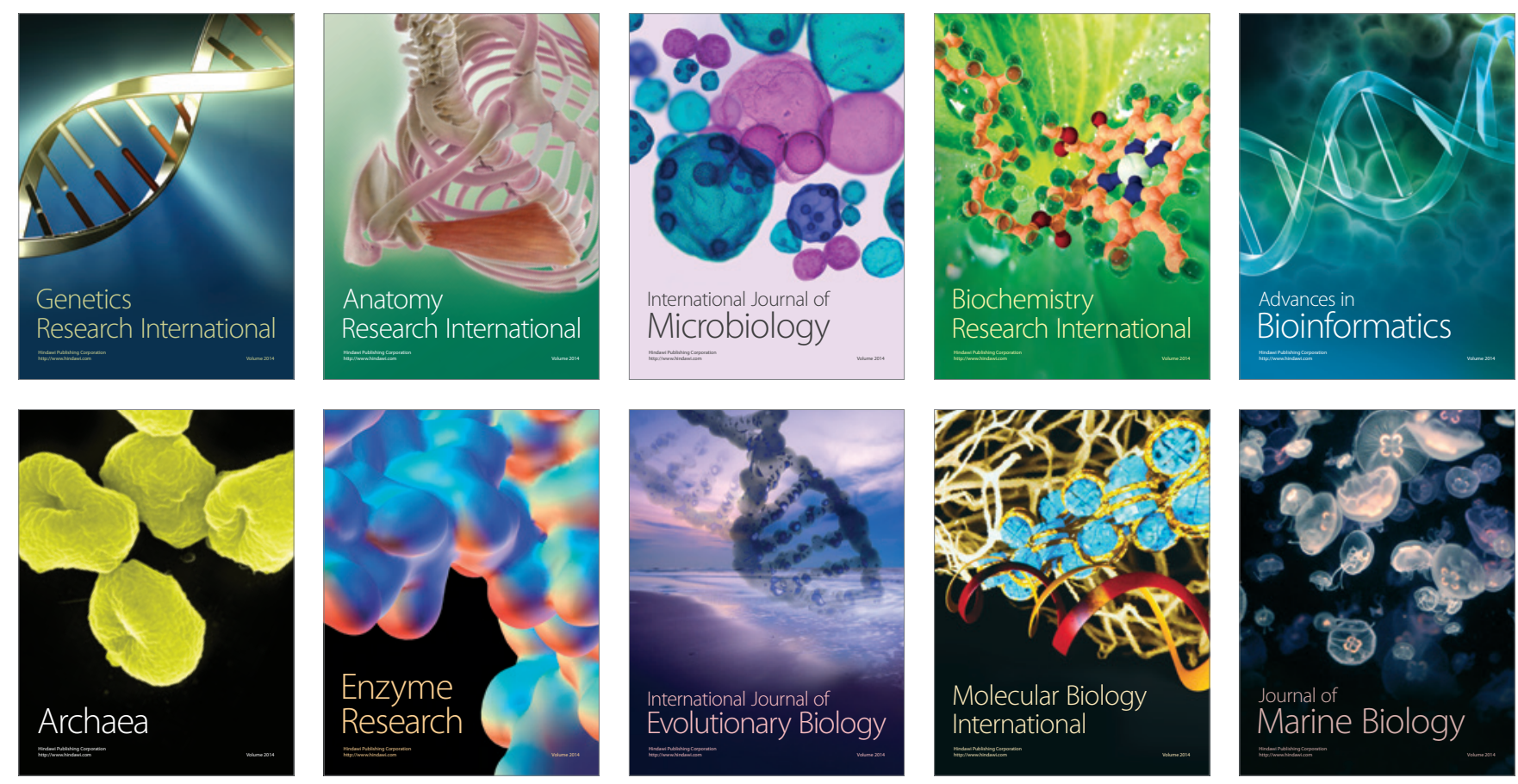